\title{
Pemberdayaan Kelompok Ibu Rumah Tangga Desa Tambaan Kecamatan Camplong Kabupaten Sampang Provinsi Jawa Timur
}

\author{
Arin Wildani ${ }^{1}$, Iswahyudi ${ }^{2}$, Mohammad Taufiq Hidayat ${ }^{3}$, Agus Budiyono ${ }^{4}$, Evi Malia ${ }^{5}$ \\ ${ }^{1}$ Pendidikan Fisika, FKIP, Universitas Islam Madura-JL.PP.Miftahul Ulum Bettet Pamekasan \\ ${ }^{2}$ Agroteknologi, Fakultas Pertanian, Universitas Islam Madura-JL.PP.Miftahul Ulum Bettet Pamekasan \\ ${ }^{3}$ Ilmu Perikanan, Fakultas Pertanian, Universitas Islam Madura-JL.PP.Miftahul Ulum Bettet Pamekasan \\ E-mail: arinwildani@gmail.com No. HP 081937288404
}

\begin{abstract}
ABSTRAK
Ibu rumah tangga memiliki peran dan potensi yang sangat strategis dalam mendukung program pengentasan kemiskinan di Indonesia. Karena itu, program pemberdayaan ibu rumah tangga dalam bidang ekonomi perlu dimaksimalkan. Program kemitraan masyarakat (PKM) ini dilakukan dengan tujuan untuk memaksimalkan peran serta ibu rumah tangga dalam mengisi waktu luangnya untuk meningkatkan pendapatan keluarga. Mitra pada program ini yaitu kelompok ibu rumah tangga Dusun Gayam dan kelompok ibu rumah tangga Dusun Pesisir Desa Tambaan Kecamatan Camplong Kabupaten Sampang. Masalah yang dihadapi mitra yaitu kurangnya pengetahuan untuk berwirausaha dan minimnya keterampilan yang dimiliki. Berdasarkan hasil observasi lapangan Desa Tambaan memiliki terdapat banyak tambak garam dan sebagian besar masyarakatnya merupakan petani garam. Sehingga pada program ini ditawarkan solusi yaitu pelatihan dan pendampingan dalam produksi garam yodium skala rumah tangga. Program ini dilakukan dengan metode penyuluhan, pelatihan dan pendampingan. Penyuluhan yang dilakukan antara lain penyuluhan pentingnya konsumsi garam beryodium dan penyuluhan wirausaha dalam skala rumah tangga. Pelatihan yang dilakukan yaitu pelatihan pembuatan hingga pengemasan garam yodium. Hasil dari PKM ini yaitu (1) kelompok IRT Dusun Gayam dan Dusun Pesisir mengetahui pentingnya garam yodium sehingga tidak lagi menggunakan garam krosok yang diambil langsung dari tambak. (2) kelompok IRT Dusun Gayam dan Dusun Pesisir bisa membuat garam yodium dengan mengolah garam krosok yang di dapat dari tambak. (3) kelompok IRT Dusun Gayam dan Dusun Pesisir memahami usaha garam yodium skala rumah tangga. (4) kelompok IRT Dusun Gayam dan Dusun Pesisir memproduksi garam yodium dan menjual garam tersebut.
\end{abstract}

Kata Kunci : garam yodium; kelompok ibu rumah tangga; keterampilan hardskill

\section{ABSTRACT}

Housewives have a very strategic role and potential in supporting poverty alleviation programs in Indonesia. Therefore, the empowerment program for housewives in the economic field needs to be maximized. This community partnership program (PKM) is carried out with the aim of maximizing the participation of housewives in filling their free time to increase family income. Partners in this program are a group of housewives from Gayam Hamlet and a group of housewives from Pesisir Hamlet, Tambaan Village, Camplong District, Sampang Regency. The problems faced by partners are the lack of knowledge for entrepreneurship and the lack of skills possessed. Based on the results of field observations, Tambaan Village has many salt ponds and most of the people are salt farmers. So that this program offered solutions namely training and assistance in the production of household-scale iodine salt. This program is carried out with counseling, training and mentoring methods. Counseling was carried out, among others, on the importance of consumption of iodized salt and entrepreneurship counseling on a household scale. The training was carried out namely training in making up to packaging iodine salt. The results of this PKM are (1) the Dusun Gayam 
and Pesisir IRT groups know the importance of iodine salt so that they no longer use crossover salt taken directly from the pond. (2) the IRT Dusun Gayam and Coastal Hamlet groups can make iodine salt by processing the krosok salt obtained from the pond. (3) the IRT Dusun Gayam and Pesisir groups understand the household-scale iodine salt business. (4) the IRT Dusun Gayam and Dusun Pesisir groups produce iodine salt and sell the salt.

Keywords : iodine salt; housewife group; hard skills

\section{PENDAHULUAN}

Kabupaten Sampang merupakan salahsatu kabupaten yang ditetapkan sebagai daerah tertinggal di Jawa timur. Sebagai daerah tertinggal maka Kabupaten Sampang memiliki berbagai permasalahan terutama dalam sektor ekonomi. Desa Tambaan Kecamatan Camplong merupakan salahsatu desa yang termasuk dalam wilayah Kabupaten Sampang. Sektor ekonomi yang belum berkembang berpengaruh pada pendapatan masyarakat Kabupaten Sampang terutama pada daerah-daerah pinggiran kota atau daerah pesisir seperti Desa Tambaan Kecamatan Camplong. Faktor pemicu lainnya yaitu rendahnya pendidikan masyarakat sehingga berdampak pada rendahnya penguasaan ilmu pengetahuan dan teknologi.

Transfer pengetahuan dan teknologi sangat diperlukan masyarakat sehingga masyarakat dapat melakukan pengembangan usaha. Peluang masyarakat dalam rangka meningkatkan taraf hidupnya sangat besar, karena sangat banyak sektorsektor ekonomi yang masih bisa dikembangkan seperti memanfaatkan potensi sumber daya alam. Pada hakekatnya,Kabupaten Sampang memiliki potensi sumber daya alam yang melimpah. Salahsatunya yaitu laham garam yang luas seperti yang terdapat di
Desa Tambaan Kecamatan Camplong. Potensi tersebut belum dioptimalkan oleh masyarakat.

Ibu rumah tangga memiliki peran dan potensi yang sangat strategis dalam mendukung program pengentasan kemiskinan di Indonesia. Karena itu, program pemberdayaan ibu rumah tangga dalam bidang ekonomi perlu dimaksimalkan. Program Kemitraan Masyarakat (PKM) ini dilakukan dengan tujuan untuk memaksimalkan peran serta ibu rumah tangga dalam mengisi waktu luangnya untuk meningkatkan pendapatan keluarga. Mitra pada program ini yaitu kelompok ibu rumah tangga Dusun Gayam dan kelompok ibu rumah tangga Dusun Pesisir Desa Tambaan Kecamatan Camplong Kabupaten Sampang. Kedua mitra tersebut termasuk dalam kelompok masyarakat tidak produktif secara ekonomi. Kedua mitra tersebut hanya mengandalkan pendapatan yang diperoleh suami.

Ketersediaan bahan baku garam mentah memungkinkan untuk diproduksi menjadi garam yodium dalam skala rumah tangga. Garam yodium merupakan salah satu kebutuhan pokok konsumsi rumah tangga yang tidak dapat digantikan serta menjadi komoditas yang diperdagangkan, baik pada sektor lokal, nasional bahkan internasional. Sebagai salah satu kebutuhan pokok konsumsi maka garam akan selalu dibutuhkan khususnya bagi kaum ibu-ibu rumah tangga sebagai bahan 
tambahan makanan. Sehingga produksi garam yodium memiliki peluang yang besar dalam pemasarannya.

Berdasarkan hasil wawancara dengan kedua mitra mengenai produksi garam yodium skala rumah tangga didapatkan kedua mitra sangat antusias untuk memproduksi garam yodium namun terdapat beberapa permasalahan mitra antara lain kurangnya pengetahuan akan pentingnya garam beryodium, kurangnya pengetahuan proses pengolahan garam murni menjadi garam yodium, tidak tersedianya alat untuk memproduksi garam beryodium dan kurang pengetahuan dalam manajemen suatu usaha.

Oleh karena itu maka perlu diberikan dorongan, bimbingan dan pendampingan bagi masyarakat Desa Tambaan. Bimbingan tersebut dilakukan dengan memberikan penyuluhan dan pelatihan mulai dari penyuluhan pentingnya garam beryodium, pelatihan pembuatan garam yodium hingga pendampingan dalam proses produksi, pengemasan dan manajemen usaha. Mitra dari program ini yaitu kelompok ibu rumah tangga Dusun Gayam dan kelompok ibu rumah tangga Dusun Pesisir Desa Tambaan Kecamatan Camplong Kabupaten Sampang.

\section{METODE KEGIATAN}

Berdasarkan permasalahan dan solusi yang telah diuraikan maka langkah langkah dalam melaksanakan solusi permasalahan mitra adalah sebagai berikut:

\subsection{Penyuluhan, Pemaparan dan Diskusi}

Penyuluhan dilakukan berkaitan tentang pentingnya garam yodium dan penyuluhan kewirausahaan. Sosialisasi dilakukan dengan pemaparan dan diskusi tentang masalah yang dihadapi mitra. Pemaparan dan diskusi diarahkan terhadap permasalahan mitra yaitu pentingnya garam beryodium, usaha garam yodium skala rumah tangga, wirausaha yang baik. Pemaparan dan diskusi juga diarahkan terhadap peluang-peluang usaha mitra yang ada.

\subsection{Pelatihan Pembuatan Garam} Yodium

Pelatihan pembuatan garam yodium dilakukan untuk meningkatkan keterampilan masyarakat Desa Tambaan. Pembuatan garam yodium meliputi beberapa langkah seperti pada gambar 1 .

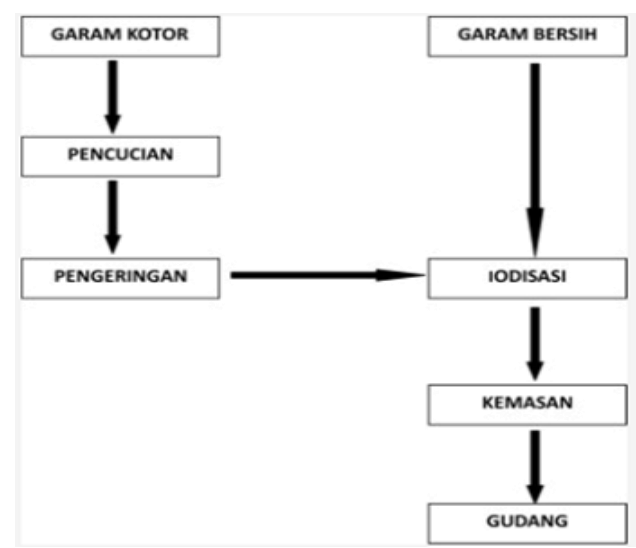

Gambar 1. Proses pembuatan garam yodium

Pencucian garam dilakukan jika garam yang digunakan merupakan garam kotor. Pencucian dimaksudkan untuk membersihkan garam dari kotoran yang terkandung dalam garam berupa pasir atu lumpur. Larutan pencuci yang digunakan yaitu larutan garam jenuh atau Brine dengan kepekatan antara 20-25 Be dengan kandungan magnesium (Mg) mak 10 
PPM. Perbandingan larutan pencuci terhadap garam minimal 1:6.

Larutan garam dapat dibuat pada bak-bak yang saling berhubung sehingga larutan dapat mengalir dari bak awal ke bak akhir secara limpahan (over flow). Proses pencucian dilakukan dengan memasukan kristalisasi garam kedalam bak-bak penampung yang berisi larutan pencuci brine lalu secara mekanis garam dipindahkan dari bak pertama sampai ke bak terakhir.

Garam yang sudah dicuci selanjutnya dikeringkan. Pengeringan dilakukan dengan menjemur garam dan dibiarkan sampai beberapa hari. Proses selanjutnya yaitu proses iodisasi dengan mencampur garam dengan larutan kalium iodat dengan standar kadar iodium 50 ppm, artinya 50 iodium per kilogram garam. Perbandingan $\mathrm{KIO}_{3}$ dan air terlihat pada tabel 2 .

Tabel 2. Perbandingan Garam $\mathrm{KIO}_{3}$ dan Air untuk Mendapatkan Garam yang Memenuhi Syarat $50 \mathrm{ppm}$

\begin{tabular}{ccc}
\hline Garam (kg) & $\mathbf{K I O}_{\mathbf{3}}$ (gr) & Air (Liter) \\
\hline 50 & 2,5 & 0,05 \\
\hline 100 & 5 & 0,10 \\
\hline 200 & 10 & 0,20 \\
\hline 300 & 15 & 0,30 \\
\hline 400 & 20 & 0,40 \\
\hline 500 & 25 & 0,50 \\
\hline 600 & 30 & 0,60 \\
\hline 700 & 35 & 0,70 \\
\hline 800 & 40 & 0,80 \\
\hline 900 & 45 & 0,90 \\
\hline 1000 & 50 & 1 \\
\hline
\end{tabular}

\subsection{Penyuluhan, Pemaparan dan diskusi}

Proses transfer ilmu pengetahuan dilakukan dengan metode penyuluhan. Materi yang disampaikan yaitu 1) Dampak mengkonsumsi garam murni (garam tambak). 2) Pentingnya mengkonsumsi garam beryodium dan 3)Prospek industri garam beryodium skala rumah tangga. Total peserta penyuluhan yaitu 20 peserta, 10 peserta dari mitra 1 dan 10 peserta dari mitra 2. Seluruh peserta sangat antusias terhadap materi yang disampaikan. Hal tersebut dapat dilihat dari hasil umpan balik kegiatan penyuluhan untuk 3 materi yang telah disampaikan. Hasil umpan balik dapat dilihat pada tabel 1 dimana untuk materi 1 didapatkan $35 \%$ menyatakan materi 1 penting dan $65 \%$ menyatakan sangat penting. Sedangkan untuk materi 2 didapatkan $15 \%$ menyatakan penting dan $85 \%$ menyatakan sangat penting sementara untuk materi 3 didapatkan $40 \%$ menyatakan penting dan $60 \%$ menyatakan sangat penting.

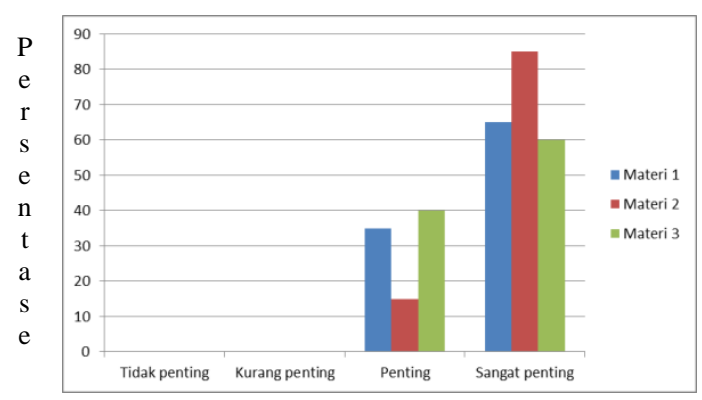

Gambar 2. Hasil umpan balik penyuluhan

Dokumentasi kegiatan penyuluhan dari kegiatan penyuluhan dapat dilihat pada gambar 3 .

\section{KARYA UTAMA}




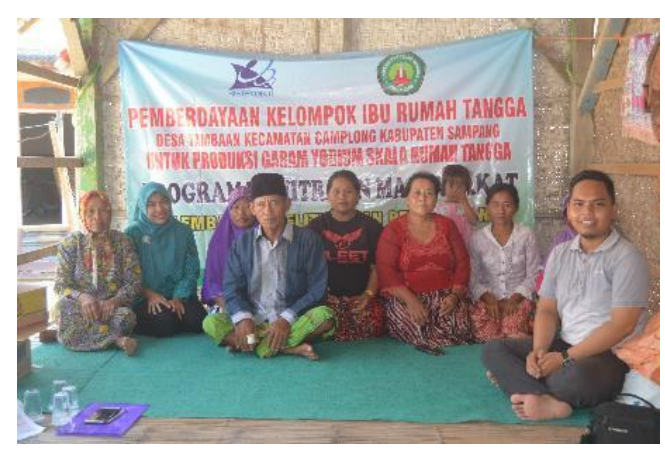

(a)

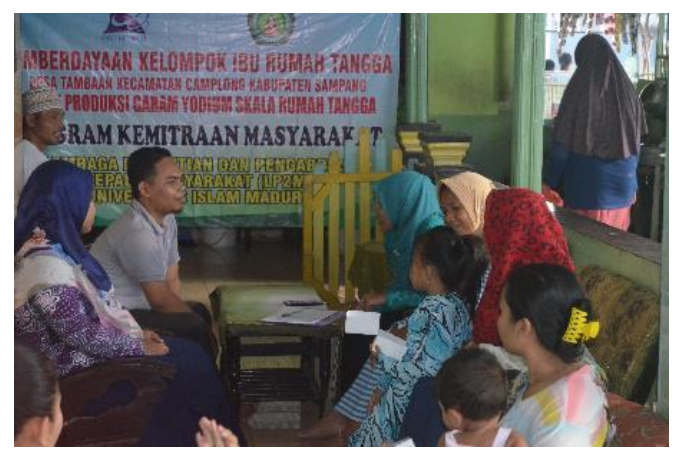

(b)

Gambar 3. Dokumentasi kegiatan penyuluhan
a) mitra 1
b) mitra 2

\subsection{Pelatihan pembuatan garam yodium}

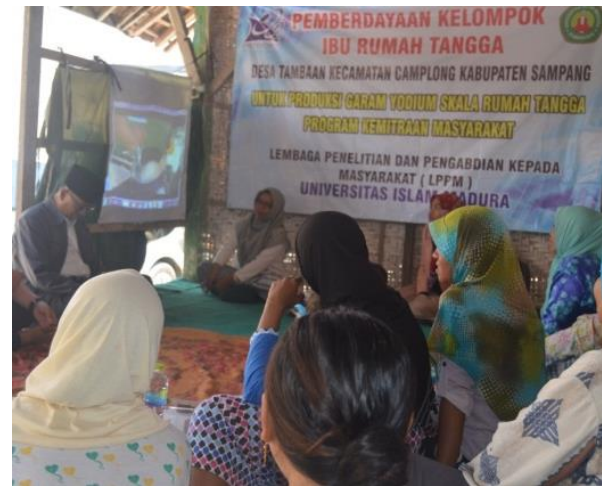

Gambar 4. Pemaparan proses pembuatan garam yodium

Pelatihan pembuatan garam yodium dilakukan dengan pemaparan dan diskusi cara membuat garam yodium seperti terlihat pada gambar 4. Selanjutnya para peserta langsung praktek membuat garam yodium. Gambar 5 memperlihatkan kegiatan pelatihan pembuatan garam yodium.

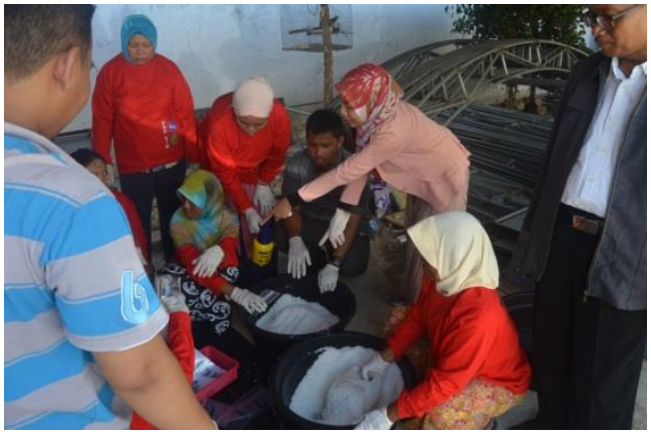

(a)

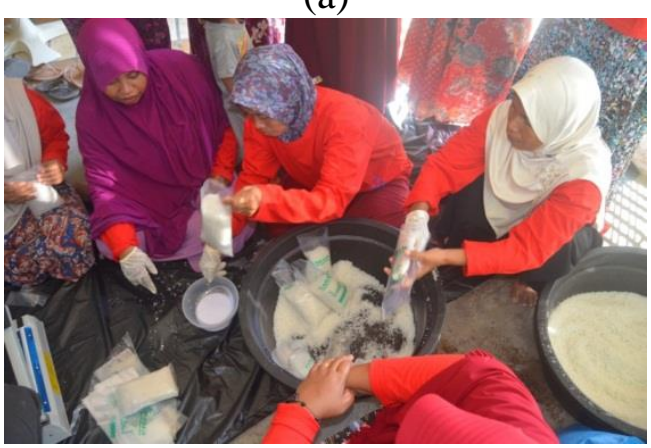

(b)

Gambar 5. Proses pembuatan garam yodium

Garam yodium yang dibuat kemudian dikemas dengan kemasan 250 gram sepeti terlihat pada Gambar 6.

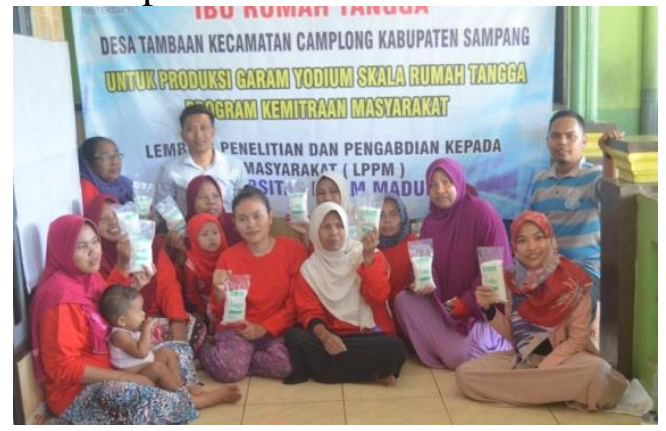

Gambar 6. Kemasan garam yodium

\section{ULASAN KARYA}

Garam yodium yang diproduksi masyarakat Desa Tambaan kemudian di uji pasar ke masyaarakat sekitar Desa Tambaan. Dari hasil uji pasar terdapat beberapa kelemahan dari produk garam yodium yang telah dibuat yaitu 1) garam yang diproduksi masih garam kasar 2) kemasan masih kurang menarik 3) peralatan untuk produksi masih kurang 
lengkap namun garam yodium memiliki peluang pasar yang bagus mengingat tersedianya garam yang melimpah.

\section{DAMPAK DAN MANFAAT KEGIATAN}

Dampak jangka pendek dari kegiatan ini antara lain:

1. Menghasilkan kelompok wirausaha skala rumah tangga dengan produk garam beryodium.

2. Meningkatnya pengetahuan keluarga petani garam.

3. Meningkatkan pengetahuan masyarakat akan pentingnya mengkonsumsi garam beryodium.

Sementara dampak jangka panjang antara lain:

a. Menghasilkan keluarga petani garam yang mampu menjalankan usaha garam beryodium skala rumah tangga.

b. Diperoleh suatu generasi yang baik dengan mengkonsumsi garam beryodium.

Keuntungan dan manfaat yang diharapkan dari kegiatan ini adalah:

a. Kelompok masyarakat Desa Tambaan mengenal manfaat mengkonsumsi garam beryodium dan dapat menularkan pada seluruh masyarakat desa

b. Kelompok masyarakat Desa Tambaan mempunyai kemampuan dalam membuat garam beryodium skala rumah tangga.

c. Membina hubungan antar Perguruan Tinggi dengan masyarakat sebagai bentuk transfer pengetahuan dan bersama-sama menyiapkan calon generasi muda yang lebih baik lagi.

\section{KESIMPULAN}

Berdasarkan pemaparan diatas makan dapat disimpulkan bahwa para ibu rumah tangga petani garam Dusun Gayam dan Dusun Pesisir sangat antusias dengan adanya Program Kemitraan Masyarakat yang diselenggarakan oleh Universitas Islam Madura untuk meningkatkan kualitas Ibu rumah tangga petani garam.

Program PKM mampu meningkatkan pengetahuan dan jiwa wirausaha terhadap kelompok ibu rumah tangga petani garam. Terwujudnya hubungan baik antara perguruan tinggi dan kelompok ibu rumah tangga petani garam di Kabupaten Sampang.

\section{PENGHARGAAN}

Terimakasih disampaikan kepada kemensristekdikti yang telah mendanai kegiatan ini melalui hibah Program Kemitraan Masyarakat (PKM) tahun anggaran 2018.

\section{DAFTAR PUSTAKA}

[1]. Heriansah dan Fathuddin. 2014.Analisis Tata Niaga Garam Untuk Pengembangan Usaha Garam Rakyat di Kabupaten Pangkep.Jurnal Balik Diwa, Vol:5, No:2, Hal 1-9

[2]. Hakim,A.L., 2009. Kesesuaian Kadar Yodium Garam Dapur, Air dan Urin Iodium Excretion (UIE) di Daerah Endemis Gaky.Skripsi.Prodi Ilmu Gizi. Fakultas Kedokteran. Universitas Diponegoro.Semarang

[3]. Noviyanto.2014.Peningkatan Nilai Ekonomis Garam Madura Melalui Variasi Warna Yodium. Jurnal PeloporPendidikan.Volume:7,No:1. Hal 10-18 